\title{
Glacial cirque formation in northern Scandinavia
}

\author{
Cecilia Richardson and Per Holmlund \\ Department of Physical Geography, Stockholm Universily, S-106 91 Stockholm, Sweden
}

\begin{abstract}
Passglaciären is a small cirque glacier in the Kebnekaise massif, northern Sweden. It is frozen to its bed over more than $70 \%$ of its area, and under present climatic conditions has little effect on cirque formation. More favourable conditions for cirque glacier erosion during the Holocene are of short duration. Assuming similar conditions during previous interglacials, it is suggested that forms such as the Passglaciären cirque developed mainly during the initial phases of glacials when they were part of networks of large valley glaciers or of a small warm-based mountain-centred ice sheet. Passglaciären has been examined in order to evaluate its erosive capacity and its association with the subglacial cirque morphology. The methods used are radar surveys and direct ice-temperature measurements. Erosion is restricted to a small section of the glacier bed, at present resulting in only partial deepening of the cirque and erosion of the backwall. In cold, arid regions with extensive permafrost, small cirque glaciers are largely frozen to the bed, and therefore cannot contribute significantly to cirque formation. In such regions glacial erosion by larger temperate glaciers is more likely to be the major cause of cirque excavation.
\end{abstract}

\section{INTRODUCTION}

The aim of this study is to investigate the genesis of a cirque in northern Sweden occupied by the glacier Passglaciären. Interpretation of landforms can be used to reconstruct former climates. In these applications, it is very important to understand the climatic conditions producing specific landforms. According to the common opinion, cirque forms developed successively during the Quaternary (Enquist, 1916; Evans, 1977; Vilborg, 1977; Rudberg, 1994). Conditions for erosion by cirque glaciers are generally believed to have been most favourable during the initial stages of glaciations when cirque glaciers were formed in the mountains. Glacial cirques are common in the Scandinavian mountain range, especially in the Norwegian coastal zone. The number of cirques gradually decreases towards the eastern part of the mountain range, and here the genesis of cirques is complicated (cf. Holmlund, 1991; Rudberg, 1992). In this relatively continental part of the mountain range, the climatological settings contradict the idea that cirque glaciers are the major agents for cirque formation. The central-eastern part of the mountain range is characterised by a relatively dry climate and extensive permafrost (King, 1984). In general, cirque glaciers in this region are rather small and have low mass turnover, resulting in low erosion potential (Andrews, 1972). Permafrost may extend down to the base over large parts of thin glaciers. In these zones where the ice is frozen to the bed, the effect of glacial erosion is negligible.

The present erosive capacity of Passglaciären has been evaluated by surveys of ice thickness, vertical temperature profiles and the amount of cold-based/warm-based ice. Additional information was supplied by studies of glacial morphology and by a radiocarbon-dated sample from the proglacial area.

\section{GEOGRAPHICAL SETTINGS}

Passglaciären is a cirque glacier located in the Kebnekaise massif in the northeastern part of the Scandinavian mountain range. Kebnekaise is a high-altitude area of alpine character with summit heights of $1600-2100 \mathrm{~m}$ a.s.l. (Fig. 1). The region is characterised by predominantly westerly winds (Enquist, 1916), and, according to the accumulation pattern on Passglaciären, wind-drifted snow is a major source of accumulation (Fig. 2). The cirque glacier has an area of $0.5 \mathrm{~km}^{2}$ and a surface inclination of about $16^{\circ}$. The general ice flow is directed towards the north. Near the centre of the glacier, the surface ice velocity has been measured at about $2 \mathrm{~m} \mathrm{a}^{-1}$. At present, Passglaciären fills its cirque almost entirely, suggesting future expansion would start to infill the downstream trough valley, Kuopervagge.

\section{METHODS}

The ice depth and the thickness of the cold permafrost layer were mapped using a ground-based high-resolution radar. The radio-echo sounder is based on a Hewlett and Packard Network Analyser (8753B) (Hamran and others, 1995). In this study, two kinds of antennae were used, Allgon 7125.04.05.00 and Allgon 7104.01.05.00, with frequency ranges of $780-930$ and $315-375 \mathrm{MHz}$, respectively. The start and end points of the radar profiles were surveyed with a theodolite Wild T2 and a Geodimeter 


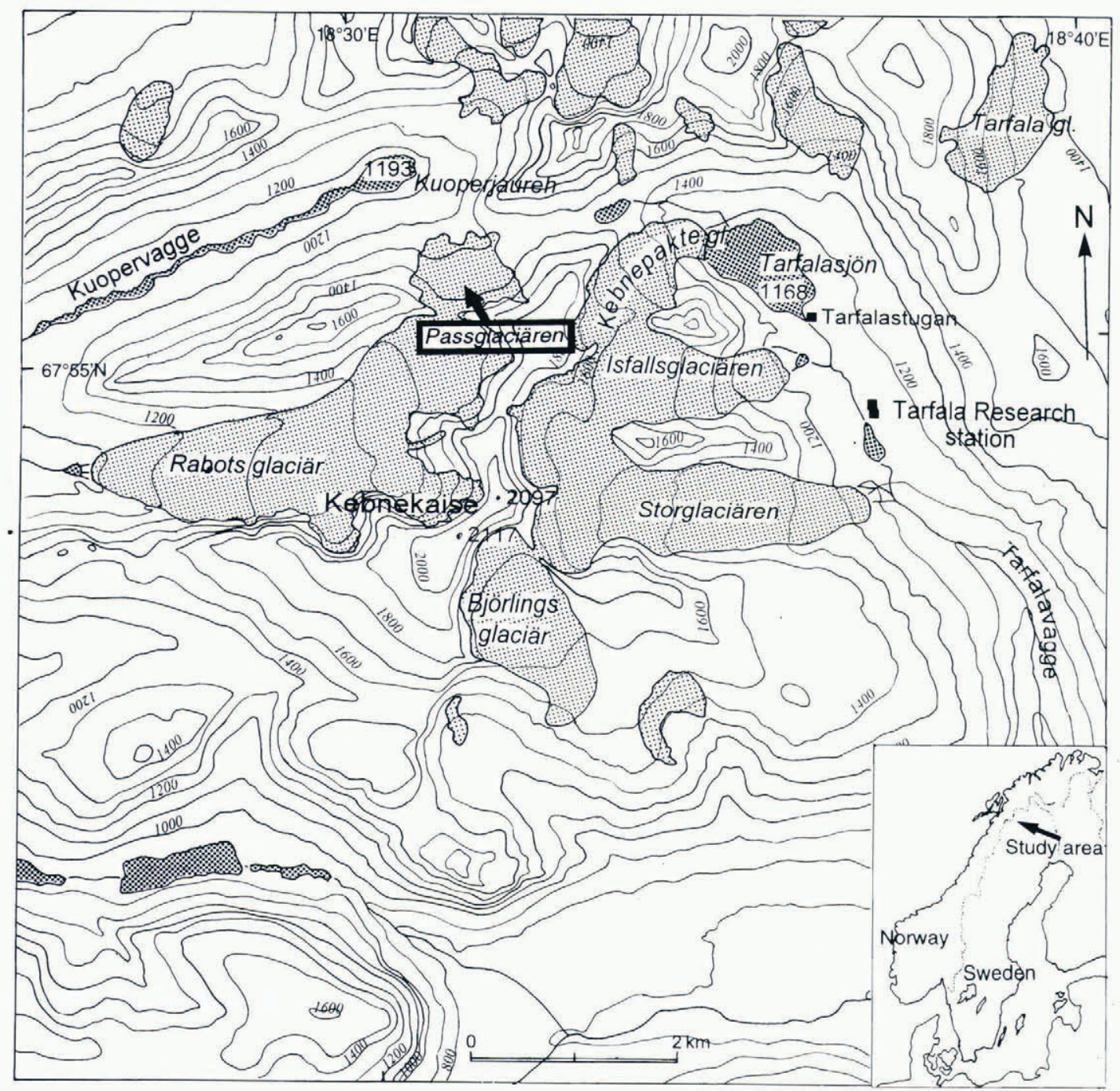

Fig. 1. Location map with a contour interval of $100 \mathrm{~m}$. The location of Passglaciären is indicated by an arrow.

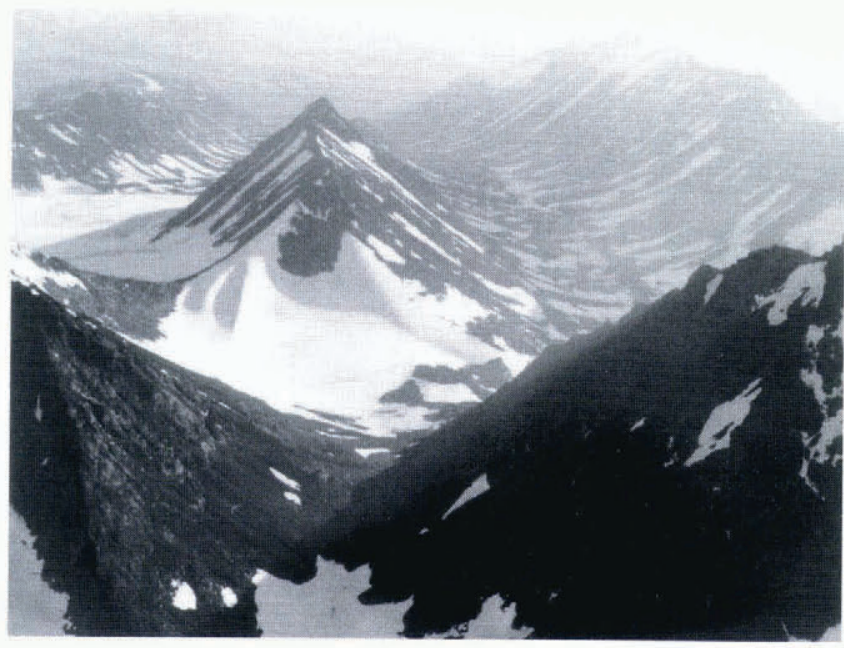

Fig. 2. Photograph of Passglaciären taken from the east. The cirque glacier is located on the eastern side of a mountain ridge, which causes a lee-side effect for the predominantly westerly winds. Passglaciären is located upstream of a $U$-shaped valley called Kuopervagge, seen at the right of the photograph.

AGA 12A. In the radar registrations, the transition from cold to temperate ice is marked by a distinct increase in the occurrence and intensity of scattered echoes within the ice Holmlund and Eriksson, 1989; Hamran and Aarholt, 1993). Geometric corrections were made manually to obtain vertical depth values from measurements performed in the direction normal to a sloping ice surface.

Vertical ice-temperature profiles were measured by thermistors installed in two boreholes along the centre line of the glacier (Fig. 3). The boreholes did not reach the glacier bed. At the upper site (A) thermistors were installed every $10 \mathrm{~m}$ down to a depth of $43.5 \mathrm{~m}$, and at the lower site (B) every $5 \mathrm{~m}$ down to $18.5 \mathrm{~m}$. To establish the seasonal temperature variations, measurements were carried out in the period from spring (April) to autumn (September).

\section{RESULTS}

The average ice depth of the glacier is $25 \mathrm{~m}$, and the maximum recorded ice depth exceeds $80 \mathrm{~m}$. The maximum area over which the glacier may be warmbased, and thus erosive, is shown on the ice depth map in Figure 4. The boundary for the warm-based parts of the glacier is primarily determined from radar surveys. In the upper part of the accumulation area, where radar profiles 


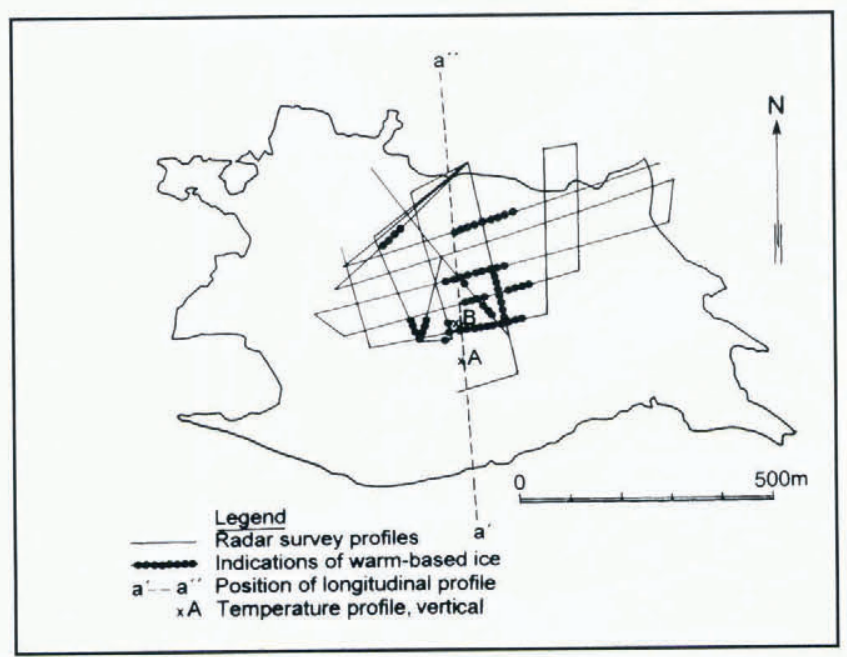

Fig. 3. Locations of boreholes and radar profiles. According to the radar surveys, the warm-based ice is patchy. $A$ and $B$ mark the positions of boreholes for measurements of vertical lemperature profiles. The dashed line $\left(a^{\prime}-a^{\prime \prime}\right)$ shows the position of the longitudinal profile seen in Figure 5.

are sparse, the boundary is delineated by the bergschrund. At least $70 \%$ of the areal extent of Passglaciären is frozen to the bed. Radar surveys indicate that the warm-based ice is patchy (Fig. 3). A longitudinal profile of Passglaciären and the thickness of the cold permafrost layer are shown in Figure 5. The cirque form has an overdeepening with a height difference up to the rock threshold of $10-30 \mathrm{~m}$. The permafrost is deepest at the glacier front, reaching about $50 \mathrm{~m}$ down in the ice. The permafrost depth decreases towards the accumulation area, which basically consists of temperate ice. The temperature profiles (Fig. 6) show that at 15-18 $\mathrm{m}$ depth there is a temperature difference of approximately $0.5^{\circ} \mathrm{C}$ between locations $\mathrm{A}$ and $\mathrm{B}$.

Bedrock is exposed at the western part of the cirque threshold, while the eastern proglacial area is covered by till. Glacial striae in front of the glacier indicate former ice-flow directions of $340-350^{\circ}$. Organic material was

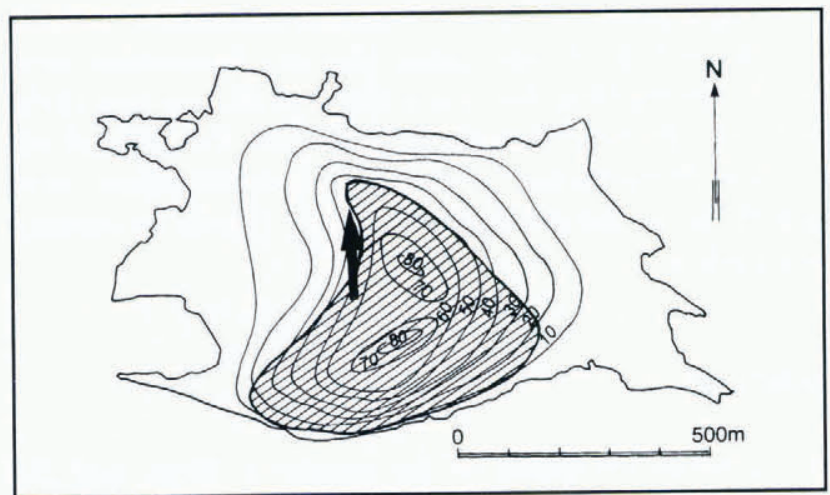

Fig. 4. Ice depth map for Passglaciären with a contour interval of $10 \mathrm{~m}$. The dashed area shows the estimated maximum extent of warm-based ice. The arrow in the central part of the glacier indicates the general ice-flow direction.

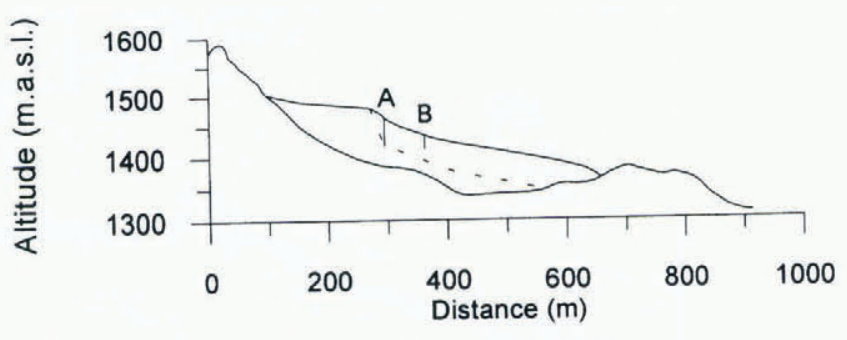

Fig. 5. Longitudinal profile of Passglaciären from south to north ( $a^{\prime}-a^{\prime \prime}$ in Figure 3). The dashed line indicates the thickness of the cold permafrost layer. A and B mark the borehole positions.

found beneath till $60 \mathrm{~m}$ in front of the glacier terminus. It was preserved in a small cavity in the stoss side of a large flat-topped boulder $\left(2-3 \mathrm{~m}^{2}\right)$. The boulder was immediately overlain by $0.1 \mathrm{~m}$ of stratified sediments of silty-tosandy fractions, in turn covered by $0.4 \mathrm{~m}$ of till. The slightly inclined sediment layers were cut off at the boulder surface. A radiocarbon dating of the organic material yielded an uncalibrated age of $3260 \pm 80$ years BP (lab. no. Ua-3795). Three meltwater streams drain Passglaciären. Only the westernmost stream contains sediment, while the other two carry clear water.

\section{DISCUSSION}

\section{Erosion potential of Passglaciären through time}

The general temperature distribution within the glacier is uncomplicated. Passglaciären is partly warm-based and partly cold-based, and can thus be classified as a subpolar

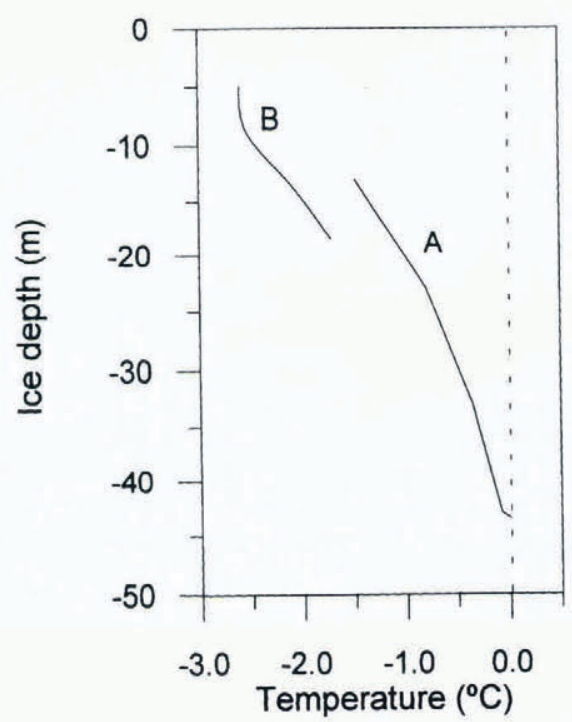

Fig. 6. Vertical temperature profiles, measured in August 1993. Seasonal temperalure variations were observed down to $15 \mathrm{~m}$. The temperature difference between $A$ and $B$ at equal depths indicates a horizontal temperature gradient between the accumulation area and the ablation area. This gradient is also reflected by the thickness of the cold permafrost layer which decreases towards the accumulation area. 
glacier. Temperate ice is restricted to the deepest part of the glacier with a displacement towards the accumulation area. The displacement is also reflected in a horizontal temperature gradient between the accumulation area and the ablation area (Fig. 6). This temperature distribution is probably due to the formation of temperate ice in the accumulation area. During summer, surface meltwater penetrates the firn and subsequently refreezes. This releases latent heat which raises the temperature of the firn and ice. In the ablation zone, this process can occur only in early summer when the ice is covered by snow, since solid ice is impermeable to meltwater. With a temperature distribution similar to the present, Passglaciären has little impact on the cirque morphology. The erosion may only result in partial deepening of the cirque.

Assuming a constant precipitation, changes in areal extent or ice thickness of a glacier have critical consequences for its erosive capacity. As mentioned, a reduction in surface area of a glacier results in smaller mass turnover and decreased erosive capacity. Furthermore, when a sub-polar glacier becomes thinner, the amount of warm-based ice decreases and, eventually, the glacier may become completely frozen to the bed. The radiocarbon date implies that prior to $3260 \pm 80{ }^{14} \mathrm{C}$ years BP, Passglaciären was smaller than, or possibly similar to, its present size. This age is in line with the termination of the Holocene hypsithermal, a climatic optimum initiated around 8500 BP (Nesje and Kvamme, 1991). Sediment studies of proglacial lakes suggest that one of the more pronounced glacier advances in Scandinavia occurred about 3200-2800 BP (Karlén, 1988). According to the same study, some Scandinavian glaciers disappeared during a warm period in the early Holocene and did not re-form until about 2000 BP. The inferred reduced size of Passglaciären during the Holocene climatic optimum implies a decreased erosive capacity of the glacier during some period prior to $3260 \pm 80$ years BP.

Recurrent cold periods, with glaciers substantially larger than at present, have prevailed for more than $90 \%$ of the time during the past $2 \mathrm{Ma}$ (Porter, 1989). Passglaciären cannot grow much larger than at present until it starts to infill the downstream valley. Thus, it may have been small enough to be classified as a cirque glacier for less than $10 \%$ of the past 2 Ma, i.e. 200000 years. It is possible that the cirque glacier completely disappeared at some stage of the Holocene, as well as during parts of previous interglacials. Its period of existence may thus have been significantly shorter than 200000 years.

Cryogenic denudation processes, which may act on ice-free surfaces, probably influence the rate of headwall retreat. However, these processes are most probably not capable of enhancing the bedrock depression during periods when the Passglaciären cirque is free from ice.

\section{Passglaciären's contribution to the cirque excavation}

Cirque formation time can be estimated based on erosion rate and a reconstructed preglacial topography (Larsen and Mangerud, 1981). For the Passglaciären cirque, two reconstructions of preglacial topography have been performed. The maximum reconstruction assumes a smoothed continuation of adjacent slopes, and the minimum reconstruction assumes a minor concavity at the valley side. The present cirque form corresponds to a maximum bedrock deepening of $210 \mathrm{~m}$ and a minimum of $120 \mathrm{~m}$.

Neither the present nor past erosion rates for Passglaciären are known. Nevertheless, the range of possible values can be narrowed by looking at erosion rates of other Scandinavian glaciers. The suspended sediment transport from Storglaciären, a valley glacier near Passglaciären (Fig. 1), corresponds to an erosion rate of $0.6 \mathrm{~mm} \mathrm{a}^{-1}$ (Schneider and Bronge, in press). In a study of several proglacial meltwater streams in Norway, the sediment transport equalled erosion rates of $0.2-0.6 \mathrm{~mm}$ $\mathrm{a}^{-1}$ Ostrem and others, 1970). The erosion rate of a Younger Dryas cirque glacier located on the Norwegian coast has been calculated as $0.5-0.6 \mathrm{~mm} \mathrm{a}^{-1}$ Larsen and Mangerud, 1981). Using the two reconstructed preglacial surfaces for the Passglaciären cirque, and a constant erosion rate of $0.6 \mathrm{~mm} \mathrm{a}^{-1}$, a mainly warm-based cirque glacier would require 200000-350000 years to develop the present cirque form. The typical erosion rate over time has probably been significantly lower. Furthermore, it is likely that there have been periods when the cirque glacier was completely frozen to the bed. Using an erosion rate of $0.3 \mathrm{mma}^{-1}$, a time period as long as 400000 700000 years is required. Considering the length of time during the Quaternary that the cirque glacier may have existed, these calculated cirque formation times strongly suggest that the cirque glacier has not been the principal agent excavating the cirque.

\section{Cirque formation under alternative glacial conditions}

A glacier with the capacity to excavate a cirque form must be warm-based all over the cirque. Situations when this condition might be fulfilled in the study area are (1) when the climate is of a pronounced maritime type producing a highly dynamic cirque glacier, or (2) when the ice covering the cirque constitutes part of the accumulation area of a larger glacier. At present, the polar front yields high cyclonic activity at the latitudes of northern Scandinavia, with frequent low pressures coming from the west. Despite this, the eastern part of the mountain range has a relatively dry continental climate. There are no indications of a pronounced maritime climate in the study area during the Holocene. In the case where the cirque constitutes part of the accumulation area of a larger glacier, this situation must have occurred several times. When the downstream valley Kuopervagge (Figs 1 and 2) was excavated, the Passglaciären cirque must have been part of the accumulation area of this large glacier. The morphological similarities between glacial cirques and overdeepenings are remarkable. Hooke (1991) describes a possible common mechanism for the development of the two features.

According to Porter (1989), the average Fennoscandian Pleistocene glacier extension corresponds to a mountain-centred ice sheet or ice field, rather than a large, more easterly-centred ice sheet covering the whole of Scandinavia. Recent numerical-model experiments of the last glaciation suggest that during the first third of the 
Weichselian the mountain areas were covered by a small ice sheet (Holmlund and Fastook, 1995). The ice-flow pattern of such an ice sheet or ice field is controlled by bed topography. The ice surface of a mountain-centred ice sheet is probably at a lower altitude than that of an ice sheet close to a maximum extent, giving warmer conditions at the ice surface. Also, a small ice sheet will be more influenced by the cyclonic activity of the westerlies, favouring surface melting in the summer and the formation of temperate ice. During the initiation of the last and earlier glacials, small temperate, or basically warm-based, erosive ice sheets probably covered the Scandinavian mountain range. Large ice sheets reach high enough altitudes for polar ice to form, which eventually may decrease the erosion rates at the bed. In case of erosion by a large ice sheet, cirque forms would probably be demolished because the ice-flow pattern is controlled by the geometry of the ice body rather than by bed topography.

If we accept the concept of a mean Pleistocene icesheet extent similar to the one suggested by Porter (1989), we may also accept long periods of glacial erosion by networks of large valley glaciers, ice fields or small mountain-centred ice sheets. It is therefore plausible that these larger glacier types have been the major eroding agents for the glacial cirque formation on the eastern side of the Scandinavian mountain range.

\section{CONCLUSIONS}

Under climatic conditions such as the present, glaciers like Passglaciären, which is largely frozen to the bed, have a limited erosive capacity and a restricted effect on cirque morphology. If the cirque glaciers are warm-based to some extent, they may have some impact on the development of overdeepenings. The large-scale form of the investigated cirque probably developed primarily when the cirque constituted part of an accumulation area of a larger glacier. During the Quaternary there have been periods more favourable for glacial erosion in this area than the present. Such periods occurred during initiations of glacials, at times when the study area was covered by networks of large valley glaciers or by a small mountain-centred ice sheet. Due to the low altitudes of these glacier types, compared to a large ice sheet, these glaciers are influenced by the cyclonic activity of the westerlies, favouring formation of temperate ice. The valley glaciers and small mountain-centred ice sheets may thus have been temperate or at least basically warmbased.

Concerning glacial cirques on the eastern side of the Scandinavian mountain range, we agree with the view that cirque forms were mainly formed in association with glaciations. However, we believe that they were not primarily formed by small cirque glaciers, but rather by large erosive glacier complexes or small ice sheets. Cirque forms are thus not good proxy data for climatic reconstructions.

\section{ACKNOWLEDGEMENTS}

This study was funded by The Swedish Natural Science Research Council (NFR), the Swedish Society for Anthropology and Geography (SSAG) and the Universities of Lund and Stockholm. We are very grateful to J.-O. Näslund for fruitful discussions and critical comments on the manuscript. Thanks to P. Jansson and W. Karlén for ideas and valuable comments. We would also like to acknowledge the staff at the Tarfala Research Station for support and assistance during the field-work. J. Boygle kindly improved the English and H. Drake assisted in drawing the illustrations.

\section{REFERENGES}

Andrews, J.T. 1972. Glacier power, mass balances, velocities and erosional potential. Z. Geomorphol., Supplementband 13, 1-17.

Enquist, F. 1916. Der Einfluss des Windes auf die Verteilung der Gletscher. Medd. Uppsala Univ. Geol. Inst., 14, 1-108.

Evans, I.S. 1977. World-wide variations in the direction and concentration of cirque and glacier aspects. Geogr. Ann., 59A (3-4), $151-175$.

Hamran, S. -E. and E. Aarholt. 1993. Glacier study using wavenumber domain synthetic aperture radar. Radio Sci., 28 (4), 559-570.

Hamran, S. -E., D. T. Gjessing, J. Hjelmstad and E. Aarholt. 1995. Ground penetrating synthetic pulse radar; dynamic range and modes of operation. 7. Appl. Geophys., 33, 7-14.

Holmlund, P. 1991. Cirques at low altitudes need not necessarily have been cut by small glaciers. Geogr. Ann., 73A (1), 9-16.

Holmlund, P. and M. Eriksson. 1989. The cold surface layer on Storglaciären. Geogr. Ann., 71A(3-4), 241-244.

Holmlund, P. and J. Fastook. 1995. A time dependent model of the Weichselian ice sheet. Quat. Int., 27, 53-58.

Hooke, R. LeB. 1991. Positive feedbacks associated with erosion of glacial cirques and overdeepenings. Geol. Soc. Am. Bull., 103 (8), 1104 1108.

Karlén, W. 1988. Scandinavian glacial and climatic fluctuations during the Holocene. Qual. Sci. Rev., 7 (2), 199209.

King, L. 1984. Zonation and ecology of high mountain permafrost in Scandinavia. Geogr. Ann., 68A(3), 131-139.

Larsen, E. and J. Mangerud. 1981. Erosion rate of a Younger Dryas cirque glacier at Kråkenes, western Norway. Ann. Glaciol., 2, 153-158.

Nesje, A. and M. Kvamme. 1991. Holocene glacier and climatic variations in western Norway: evidence for early Holocene glacier demise and multiple Neoglacial events. Geology, 19, 610-612.

Ostrem, G., T. Ziegler and S. R. Ekman. 1970. Slamtransportundersökelser i norske bre-elver 1969. Norges Vassdrags- og Elektrisitetsvesen. Vassdragsdirektoratet. Hydrologisk Avdeling. Rapport 6/70.

Porter, S. C. 1989. Some geological implications of average Quaternary glacial conditions. Quat. Res., 32 (3), 245-261.

Rudberg, S. 1992. Multiple glaciation in Scandinavia - seen in gross morphology or not? Geogr. Ann., 74A(2-3), 231- 243.

Rudberg, S. 1994. Glacial cirques in Scandinavia. Nor. Geogr. Tidsskr., 48 (4), 179-197.

Schneider, T. and C. Bronge. In press. Suspended sediment transport in the Storglaciären drainage basin. Geogr. Ann.

Vilborg, L. 1977. The cirque forms of Swedish Lapland. Geogr. Ann., 59A $(3-4), 89-150$ 